University of Nebraska - Lincoln

DigitalCommons@University of Nebraska - Lincoln

Mammalogy Papers: University of Nebraska

State Museum

Museum, University of Nebraska State

September 1967

\title{
Annotated Checklist of Bats from South Dakota
}

J. Knox Jones Jr.

University of Kansas, Lawrence.

Hugh H. Genoways

University of Kansas, Lawrence, h.h.genoways@gmail.com

Follow this and additional works at: https://digitalcommons.unl.edu/museummammalogy

Part of the Zoology Commons

Knox Jones, J. Jr. and Genoways, Hugh H., "Annotated Checklist of Bats from South Dakota" (1967).

Mammalogy Papers: University of Nebraska State Museum. 62.

https://digitalcommons.unl.edu/museummammalogy/62

This Article is brought to you for free and open access by the Museum, University of Nebraska State at DigitalCommons@University of Nebraska - Lincoln. It has been accepted for inclusion in Mammalogy Papers: University of Nebraska State Museum by an authorized administrator of DigitalCommons@University of Nebraska Lincoln. 


\section{Annotated Checklist of Bats from South Dakota}

\section{J. KNOX JONES, JR., and HUGH H. GENOWAYS}

Excepting the generalized accounts of Over and Churchill (1945), no attempt has been made previously to summarize the distribution of bats in South Dakota. In 1960, 1961, and again in 1965, field parties from the Museum of Natural Histary of The University of Kansas collected mammals in that state. Bats obtained by these parties, together with those on deposit in other institutions and the few specimens earlier reported from South Dakota by other workers (see cited literature), form the basis of the present report. Eleven species are here treated; two of these are represented in the state by two subspecies. Of the kinds (species and subspecies) listed, two are recorded from South Dakota for the first time, whereas four have been reported previously from but a single locality in the state. Much remains to be learned about the biology of bats in the Dakota region and it is our hope that this checklist will provide an incentive for additional work.

In the accounts that follow, all measurements are given in millimeters, weights are recorded in grams, and all specimens are housed in the collections of the Museum of Natural History unless otherwise noted. For the loan of material or for allowing us to study specimens in their care, we are grateful to the following persons (parenthetical abbreviations used in text to identify specimens): Dr. N. R. Whitney, Rapid City, South Dakota (NRW); Dr. Ernest J. Hugghins, South Dakota State University (SDSU); Dr. William H. Burt, University of Michigan Museum of Zoology (UMMZ); Dr. Charles O. Handley, Jr., U. S. National Museum (USNM); and Dr. Larry N. Brown, University of Wyoming (UW). We are also indebted to Dr. Glen M. Kohls of the Rocky Mountain Laboratory, Hamilton, Montana, Dr. Richard B. Loomis, Department of Biology, Long Beach (California) State College, and Dr. B. V. Peterson, Canada Department of Agriculture, Ottawa, for identification of ectoparasites. The Museum of Natural History and Department of Zoology of The University of Kansas, the Kansas University Endowment Association (Watkins Fund), and the National Science Foundation (through fellowships to student participants in 1965 under grant GE7739) helped to defray the cost of field operations.

We also acknowledge the help of Mr. Virgil Johnson, South Dakota Department of Game, Fish and Parks, who kindly issued scientific collect-

Transactions of the Kansas Academy of Science, Vol. 70, No, 2, 1967. Published September 22, 1967. 
ing permits, and the several employees of the Department, the U. S. Forest Service, and the U. S. National Park Service who aided our efforts in the field in one way or another.

\section{Myotis evotis evotis (H. Allen, 1864)}

\section{Long-eared Myotis}

Specimens examined (16).-HARDING COUNTY: $10 \mathrm{mi} . \mathrm{S}, 5 \mathrm{mi}$. W Reva, 15; $7 \mathrm{mi}$. S, 41/2 mi. E Harding, 1.

Additional record.-SHANNON COUNTY: Corral Draw (Miller and Allen, 1928:118).

The long-eared myotis is known in South Dakota only from one locality in the Badlands and from two in Harding County in the northwestern part of the state. The species may occur also in the Black Hills. To our knowledge, no hibernating individuals have been taken to date in South Dakota.

Two females obtained in Harding County on June 17 and 19, 1961, each carried a single embryo, 14 and 15 , respectively, in ctown-rump length; a young male obtained on August 6,1960, from the same place had nearly reached adult size. The testes of an August-taken adult male measured 7.5 in length. Of seven adults, four males and three females, collected $10 \mathrm{mi}$. S and $5 \mathrm{mi}$. W Reva between August 3-6, 1960, two males and all females were in fresh pelage whereas molt nearly was completed on the two remaining males. The new pelage is pale yellowish brown in contrast to the golden brown pelage of specimens taken at the same locality early in the summer of 1961 .

Myotis keenii septentrionalis ('Trouessart, 1897)

Keen's Myotis

Specimens examined (7).-BON HOMME COUNTY: Sand Creek Park [4 mi. NE Springfield], 3; 3 mi. SW Springfield, 1. CUSTER COUNTY: Custer State Park, 2 (UMMZ). PENNINGTON COUNTY: $14 \mathrm{mi}$. W Hill City, $6400 \mathrm{ft} ., 1$.

Additional record.-CUSTER COUNTY: Elk Mountain (Miller and Allen, 1928:107; Jones and Packard, 1958:150).

Myotis keenii has been recorded previously from South Dakata only on the basis of three specimens from Elk Mountain, Custer County. The population in the Black Hills of South Dakota and adjacent Wyoming may be isolated from the contiguous range of the species in the southeastern part of the state. When compared with specimens from Bon Homme County, bats from the Black Hills are somewhat darker in comparable pelage, have a narrower skull (as illustrated by zygomatic breadth, breadth of braincase, mastoid breadth, and breadth across the 
upper molars), and a slightly longer forearm. They are referred to septentrionalis because their characters fall within the range of variation present in samples of that subspecies from eastern Nebraska and eastern Kansas. Selected average measurements (extremes in parentheses) of four specimens, two males and two females, from the Black Hills (one from Pennington County and three from adjacent Weston Caunty, Wyoming), followed by those of four specimens, two males and two females, from Bon Homme County, are: forearm, 36.0 (34.9-37.0), 34.8 (33.7-35.6); greatest length of skull, 15.1 (15.0-15.3), 15.1 (14.815.3); zygomatic breadth, 8.9 (8.8-9.0), 9.4 (9.2-9.6); breadth of braincase, 7.1 (6.9-7.3), 7.4 (7.3-7.4); mastoid breadth, 7.8 (7.7-7.8), 8.2 (8.1-8.3); breadth across upper molars, 5.5 (5.4-5.6), 5.7 (5.7$5.8)$; length of maxillary tooth-row, 6.0 (5.9-6.1), 5.9 (5.8-6.0).

Little is known of the ecology of $M$. keenii in South Dakota. The specimen from Pennington County was shot at the mouth of a pine-filled draw where Myotis lucifugus, Myotis leibii, Myotis volans, and Lasiurus cinereus also were collected. Those from Bon Homme County were caught in mist nets stretched across streams; Eptesicus fuscus and Lasiurus borealis were taken in the same nets. An adult male and female collected on July 25, 1965, in Bon Homme County were molting simultaneously over both dorsum and venter, whereas molt had not begun on a female taken on July 26, 1965, at the same locality. An adult male from $3 \mathrm{mi}$. SW Springfield, captured on July 26, 1965, was completely in fresh pelage, which is paler and grayer (less brownish) than that of the other specimens mentioned.

Chiggers, Leptotrombidium myotis (Ewing), were obtained from the ears of the specimen from $14 \mathrm{mi}$. W Hill City. This parasite has not been reported heretofore from Myotis keenii or from South Dakota.

\section{Myotis leibii ciliolabrum (Merriam, 1886)}

Small-footed Myatis

Specimens examined (19).-CUSTER COUNTY: Jewel Cave, I (UW); Hell's Canyon, $13 \mathrm{mi}$. W Custer [not simply "Custer" as reported by Miller and Allen, 1928:169], 3 (USNM); Hermosa, 1 (USNM). HAAKON COUNTY: Philip, I (SDSU). HARDING COUNTY: $10 \mathrm{mi} . \mathrm{S}, 5 \mathrm{mi}$. W Reva, 8. MEADE COUNTY: Davenport Cave, $4 \mathrm{mi}$. S Sturgis, 2 (NRW). PENNINGTON COUNTY: $14 \mathrm{mi}$. W Hill City, $6400 \mathrm{ft}$., 1 . WASHABAUGH COUNTY: $14 \mathrm{mi}$. N Long Valley, 2.

Additional records.-CUSTER COUNTY: Custer (Miller and Allen, 1928: 169-refers to specimen in collection of American Museum of Natural History). PENNINGTON COUNTY: near Wall (Kohls et al., 1965:346). SHANNON COUNTY: Corral Draw, Pine Ridge Indian Reservation (Miller, 1897:73). WASHABAUGH COUNTY: Cottonwood Creek, White River (Stebler, 1939:388). 
This saxicolous species may be limited in South Dakota to the West River counties. It is a common inhabitant of the Badlands to the east of the Black Hills and of the pine-clad buttes of Harding County. The easternmost records in the state are from Philip, along the Bad River, and in the breaks south of the White River in Washabaugh County, but the small-footed myotis likely occurs along other eastward-flowing rivers, pershaps as far east as the Missouri itself. This bat is known to hibernate in Jewel Cave and in Davenport Cave, Meade County.

No records of embryos are available among the specimens examined; however, most summer-taken individuals examined were males (all but one of 11 specimens in the Museum of Natural History, for example). Females of this species ordinarily bear but a single young as in other South Dakotan members of the genus. A male from Harding County (June 23) was molting over most of the body and a male and female from Washabaugh County (July 11) evinced the first stages of molt.

We tentatively follow Glass and Baker (1965) in use of the specific name leibii for this bat, formerly known as Myotis subulatus.

\section{Myotis lucifugus carissima Thomas, 1904}

Little Brown Myotis

Specimens examined (34).-CUSTER COUNTY: Jewel Cave, 5280 gt., 20 (8 UW). HARDING COUNTY: $2 \mathrm{mi}$. N, $5 \mathrm{mi}$. W Ludlow, $1 ; 4 \mathrm{mi}$. S, $7 \mathrm{mi}$. W Ladner, 1; $10 \mathrm{mi}$. S, $5 \mathrm{mi}$. W Reva, 1. PENNINGTON COUNTY: Beaver Creek, $4 \mathrm{mi}$. N, $10 \frac{1 / 2}{\mathrm{mi}}$. W Deerfield, $6400 \mathrm{ft} ., 8 ; 3 \mathrm{mi}$. N, $7 \mathrm{mi}$. W Deerfield, 6900 ft., 1; $14 \mathrm{mi}$. W Hill City, $6400 \mathrm{ft}$., 2.

The little brown myotis evidently is widespread and fairly common in the Black Hills and occurs at least sparingly in northwestern South Dakota. The subspecies carissima has not been reported previously by name from the state.

Only adult males were collected in the Black Hills in June and July of 1965 , indicating that females probably were congregated in maternal colonies at that time of year. Both sexes have been found hibernating in Jewel Cave in November and both have been taken in June in Harding County. Testes of males taken in June and early July varied from 2 to 5 in length.

A male taken on July 7, 1965, in Pennington County was in an early stage of molt-new hairs were found beneath the old pelage in the middorsal region and behind the ears. None of 25 other specimens taken in late spring and early summer (prior to July 7) evidenced molt. Chiggers, Leptotrombidium myotis (Ewing), were found in the ears of three specimens from Pennington County. 
Visher (1914:91) reported this bat from Harding County (under the name Myotis lucifugus lucifugus) as: "Abundant about the groves along the Little Missouri and in the forest reserves." In our experience, lucifugus is the least common of the four species of Myotis occurring in Harding County, being outnumbered by volans, evotis, and leibii (in that order). Visher listed no other species of Myotis from the county.

One specimen examined from Jewel Cave, obtained on August 31, 1966 , by a field party from the University of Wyoming, was an albino.

\section{Myotis lucifugus lucifugus (Le Conte, 1831)}

\section{Little Brown Myotis}

Specimens examined (2).-GREGORY COUNTY: Cedar Island, 1 (USNM). STANLEY COUNTY: Ft. Pierre, 1 (USNM).

We tentatively follow Miller and Allen (1928:45-46) in referring the two specimens examined, both from along the Missouri River, to the subspecies lucifugus. One is a skull alone and the other is represented by a faded specimen in spirits from which the skull has been removed.

In all probability these two specimens fall within the zone of intergradation between the subspecies carissima and lucifugus and we await additional material from the eastern and central parts of the state before assigning them definitely to one or the other. $M$. l. carissima differs from $M$. l. lucifugus in being paler and in averaging slightly larger in some cranial dimensions.

Myotis thysanodes pahasapensis Jones and Genoways, 1967 Finge-tailed Myotis

Specimens examined (8).-CUSTER COUNTY: Custer State Park, 1 (UMMZ); Jewel Cave, 6 (1 UMMZ, 4 UW); 3 mi. N Hot Springs, 1 (UW).

This fringe-tailed bat has been taken in South Dakota only in Custer County, but additional collecting likely will produce specimens from other counties along the western border of the state. The subspecies pabasapensis, as presently known, is restricted to the Black Hills of South Dakota and Wyoming (see Jones and Genoways, 1967:234).

$M$. thysanodes first was reported from South Dakota by Bole (1935: 147-148) on the basis of two bats taken at Jewel Cave on August 10, 1929. Thirty years elapsed before the species was again recorded from the Black Hills (from Jewel Cave by Thompson, Bat Research News, $6: 37,1965)$, although two specimens taken in the intervening years were reported as Myotis evotis-a young female from Custer State Park (Stebler, 1939:389) and an adult male from 11/2 mi. E Buckhorn, Wyoming (Long, 1965:532). In July of 1965, members of a field party from the Musuem of Natural History netted a male thysanodes at the 
entrance to an abandoned mine in Westan County, Wyoming. Later in the same summer, Larry N. Brown and associates of The University of Wyoming captured a male at Jewel Cave and in the summer of 1966 collected five additional specimens in Custer County.

We do not know the means by which the two specimens taken in 1929 at Jewel Cave were captured nor do we know the conditions under which the bat from Custer State Park was obtained. All other specimens examined from South Dakota were captured in mist nets-five (four males and a female) at the entrance to Jewel Cave and one female over a creek north of Hot Springs.

It is not surprising that thysanodes from the Black Hills have been identified in the past as evotis. We had difficulty separating the two species in the early phases of our study. Upon direct comparison, thysanodes can be distinguished from evotis on the basis of longer forearm, shorter ear, average larger cranial dimensions (see Table 1), usually conspicuous fringe of hairs on the free border of the uropatagium (inconspicuous or absent in evotis), better developed sagittal crest, slightly higher and more inflated braincase, and somewhat more robust molar teeth.

We know of no specimens of Myotis evotis obtained in the Black Hills and, as previously stated, we have no records of $M$. thysanodes from outside the Black Hills. It is possible that the two species are more or less ecologically separated in the region, although our meager data are not sufficient to establish this point.

Table 1. External and cranial measurements of Myotis evotis and Myotis thysanodes from South Dakota. Superscript numbers indicate fewer specimens averaged than noted in headings of the two columns.

\begin{tabular}{lrc}
\hline \hline Measurement & $\begin{array}{c}\text { evotis, Harding County } \\
12(98,3 q)\end{array}$ & $\begin{array}{c}\text { thysanodes, Custer County } \\
6(4 \delta, 2 \%)\end{array}$ \\
\hline Total length & $93.4(87-100)$ & $92.7(90-96)$ \\
Length of tail & $40.2(34-45)$ & $41.2(40-44)$ \\
Length of hind foot & $9.7(8-11)$ & $10.7(10-11)^{6}$ \\
Length of ear & $20.5(19-22)$ & $18.8(17.5-21)$ \\
Length of forearm & $38.6(36.9-39.3)$ & $41.2(39.2-43.3)$ \\
Greatest length of skul1* & $16.3(15.8-17.0)^{11}$ & $16.8(16.4-17.0)$ \\
Zygomatic breadth & $9.7(9.5-10.1)^{11}$ & $10.2(10.0-10.5)^{4}$ \\
Postorbital constriction & $3.8(3.5-4.0)$ & $3.9(3.7-4.1)$ \\
Breadth of braincase & $7.4(7.2-7.8)$ & $7.8(7.4-8.1)$ \\
Mastoid breadth & $8.1(7.5-8.4)^{11}$ & $8.4(8.3-8.6)$ \\
Length of maxillary tooth-row & $6.2(6.0-6.4)$ & $6.4(6.1-6.8)$ \\
Breadth across M3-M3 & $6.2(6.0-6.5)$ & $6.6(6.4-6.9)$ \\
Breadth across upper canines & $3.8(3.6-3.9)^{11}$ & $4.0(3.8-4.1)$ \\
\hline
\end{tabular}

* includes incisors 
Myotis volans interior Miller, 1914

Long-legged Myotis

Specimens examined (58).-CUSTER COUNTY: Bull Springs, $6500 \mathrm{ft}$. [2 mi. N, 9 mi. W Custer], I (UMMZ); Jewel Cave, $5280 \mathrm{ft}$., 9 (3 NRW, I UW); Wind Cave National Park, headquarters, 1 (UMMZ). HARDING COUNTY: 2 mi. N, 5 mi. W Ludlow, 4; 10 mi. S, 5 mi. W Reva, 26. LAWRENCE COUNTY: $2 \mathrm{mi}$. S Tinton, $6100 \mathrm{ft}, 1$. PENNINGTON COUNTY: Beaver Creek, $4 \mathrm{mi}$. N, $101 / 2 \mathrm{mi}$. W Deerfeld, $6400 \mathrm{ft} ., 3 ; 14 \mathrm{mi}$. W Hill City, $6400 \mathrm{ft}$., 11; Bear Trap Cave, $4 \mathrm{mi}$. S, $16 \mathrm{mi}$. W Hill City, $6000 \mathrm{ft}$., 1; no specific locality, I (NRW).

Myotis volans has been reported previously in South Dakota on the basis of a single specimen from Bull Springs, $6500 \mathrm{ft}$., Custer County (Moulthrop, 1936:413). This bat, however, appears to be the commonest species of the genus in the Black Hills and the pine-clad buttes of Harding County. Its distribution in the state evidently is limited to the extreme western counties, where it is resident throughout the year (hibernating individuals have been taken in Jewel Cave in November).

Two females obtained on June 29 and 30, 1961, in Harding County each contained a single embryo (one measured 20 and the other 22 in crown-rump length). A female obtained on August 3, 1960, in the same county was lactating. The testes of three males collected at Jewel Cave on June 13, 1965, each measured 2. Two males from $10 \mathrm{mi}$. S, $5 \mathrm{mi}$. W Reva (obtained June 16 and 23, 1961), and a male from $2 \mathrm{mi}$. S Tinton (obtained July 16, 1961), evidence the beginning of molt; new hairs can be observed over much of the body under the old pelage.

Four bats examined from Pennington County harbored bat flies, Basilia forcipata Ferris, which constitute the first record of this parasite from South Dakota. Another individual was parasitized by a chigger, Leptotrombidium myotis (Ewing), which has not been reported previously from $M$. volans.

\section{Lasionycteris noctivagans (Le Conte, 1831)}

\section{Silver-haired Bat}

Specimens examined (2).-DAY COUNTY: Waubay Nat'l Wildlife Refuge, 1 (USNM). PENNINGTON COUNTY: Diamond $S$ Ranch (not precisely located), 1 (UMMZ).

The silver-haired bat has not been reported previously from South Dakata. Probably it migrates through all parts of the state-northward in spring and southward in late summer and early autumn-but little is known of the actual migratory routes of this species. L. noctivagans may be resident in summer in the higher parts of the Black Hills and possibly also in the northeastern part of the state. Both of the specimens examined, a male from Pennington County (August 13, 1929) and a female from Day County (September 4, 1952), may have been migrants. 
Eptesicus fuscus fuscus (Palisot de Beauvois, 1796)

Big Brown Bat

Specimens examined (34).-BON HOMME COUNTY: Sand Creek Park [4 mi. NE Springfield], 13; Springfield, 2 (SDSU); $3 \mathrm{mi}$. SW Springfield, 17. CLAY COUNTY: Vermillion, 1 (SDSU). UNION COUNTY: Union County Park, $1200 \mathrm{ft} ., 1$.

This subspecies presently is known in South Dakota only from three counties in the southeast, but no doubt is widely distributed in the eastern part of the state. The zone of intergradation between E. f. fuscus and E. f. pallidus lies generally, at least in the southern part of the state, in the area between the 98th and 99th meridians. Specimens examined from Bon Homme County are intergrades between the two races. A few individuals from there are typical of fuscus in color but others are typical of pallidus and many fall between the two extremes. Specimens from Bon Homme County are assigned here to the larger E. f. fuscus on the basis of cranial dimensions. Findley's (1956:23) mention of a specimen from Vermillion is the only previous report from the state of a bat actually referable to this subspecies.

From July 22 to 27, 1965, Percy L. Clifton collected big brown bats in the vicinity of Springfield. Among the specimens obtained, all of which were taken in mist nets stretched across streams under cover of trees, were adults of both sexes as well as nearly adult-sized young of the year. Of 13 adult bats prepared as museum skins, six, including the four males examined, had completed (or essentially so) the annual molt, whereas seven females, one of which still was lactating, were molting. The beginning of molt probably is delayed in reproductively active females until near the end of lactation.

The annual molt of adult Eptesicus evidently takes place simultaneously over much of the body, or at least in rapid sequence, as several specimens revealed molt at essentially the same stage of progress over much of the dorsum and part of the venter. Generally, judging from the specimens at hand, molt begins middorsally in the region of the shoulders, spreads posteriad dorsally and, at the same time, ventrally to the throat and pectoral region, and thence throughout the venter. The head, cheeks, and chin frequently are the last areas where molt is completed. Old pelage seemingly is sloughed after the incoming new hair is readily visible, and sometimes is lost in patches (over the shoulders, for example) or may be lost evenly over large parts of the body so that "lines" of molt are not discernable.

Some of the young bats from Bon Homme County also were malting-from juvenal pelage to adult pelage; others had completed 
post-juvenal malt. The sequence of post-juvenal molt appears to be essentially the same as that described for adults above, excepting that the middorsal region over the shoulders and the throat may be the last places where molt is completed.

A female taken June 4, 1965, in Union County carried two embryos that measured 17 in crown-rump length. Several E. f. fuscus examined harbored ticks, Ornithodoras kelleyi Cooley and Kohls.

Eptesicus fuscus pallidus Young, 1908

Big Brown Bat

Specimens examined (56).-CUSTER COUNTY: Hell's Canyon, $13 \mathrm{mi}$. W Custer, 2 (USNM); Custer, 3 (USNM); Jewel Cave Nat'1 Monument, 1 (UW); headquarters, Wind Cave Nat'1 Park, 15 (UMMZ); Shirttail Canyon, Wind Cave Nat'l Park, 2 (UMMZ); Onyx Cave, $10 \mathrm{mi}$. NW Hot Springs, 1 (UW). HARDING COUNTY: $10 \mathrm{mi}$. S, $5 \mathrm{mi}$. W Reva, 5 . JACKSON COUNTY: $7 \mathrm{mi}$. S Kadoka, 1 (UMMZ). MEADE COUNTY: Smithville, 6 (USNM). PENNINGTON COUNTY: Rapid City, 4 (NRW); Cheyenne River, 3 mi. E Wasta, 1; Hill City, 1 (NRW); 3 mi. SE Hill City, 5300-5400 ft., 3 (UMMZ); Diamond S Ranch (not precisely located), 6 (UMMZ). SHANNON COUNTY: Quinn's Draw, Cheyenne River, 1 (USNM); White River, central part of Washington County [merger with Shannon County in 1943], 1 (USNM). STANLEY COUNTY: Ft. Pierre, 1 (USNM). WASHABAUGH COUNTY: $14 \mathrm{mi}$. N Long Valley, 2 .

Additional records.-CUSTER COUNTY: Squaw Creek [Grace Coolidge Creek] (J. A. Allen, 1895:273). MEADE COUNTY: Ft. Meade (Miller, 1897: 98). SHANNON COUNTY: Corral Draw, Pine Ridge Indian Reservation (J. A. Allen, 1895:273). TODD COUNTY: Rosebud Indian Reservation (Reagan, 1908:163). WASHABAUGH COUNTY: Cottonwood Creek at White River (Stebler, 1939:388).

The subspecies pallidus is widely distributed in the West River country and may be the commonest bat in this area. Most of the specimens seen in connection with the present report were collected in summer, but winter-taken individuals that were hibernating also have been examined-from Jewel Cave, for example. A male obtained $14 \mathrm{mi}$. N Long Valley on July 11, 1965, was molting, but no evidence of molt was found in a female taken at the same time.

Stebler (1939:388) is the only previous worker who referred to this subspecies by name from South Dakota, earlier reports having preceded the original description of E. $f$. pallidus.

Lasiurus borealis borealis (Muller, 1776)

Red Bat

Specimens examined (2).-BON HOMME COUNTY: $3 \mathrm{mi}$. SW Springfield, 1. BROOKINGS COUNTY: Brookings, 1 (SDSU).

Additional records.-CLAY COUNTY: no specific locality (Findley, 1956: 23). HYDE COUNTY: Highmore (E. J. Hugghins, personal communication). JERAULD COUNTY: Lane (ibid.). 
This migratory species probably occurs in suitable habitats over much of the East River area in the warm months of the year. The few records of occurrence doubtfully reflect the relative abundance of this bat. West of the Missouri, the red bat probably is restricted mostly to areas of deciduous timber along water courses, reaching the western limits of its resident range in South Dakota at approximately the 101st meridian (migrating individuals may pass through the western part of the state on their way to or from regions farther to the north).

A female examined from Brookings that was taken on June 29, 1953, carried two young; another from there that was captured on July 7, 1939, was accompanied by three (E. J. Hugghins, personal communication). An adult female from $3 \mathrm{mi}$. SW Springfield was netted over a small tributary of the Missouri in company with Myotis keenii and Eptesicus fuscus. Findley (1956:23) noted that April 15 was the earliest date the species had been seen in Clay County.

Lasiurus cinereus cinereus (Palisot de Beauvois, 1796) Hoary Bat

Specimens examined (10).-BON HOMME COUNTY: Sand Creek Park [4 mi. NE Springfield], 3. BROOKINGS COUNTY: Brookings, I (SDSU). CUSTER COUNTY: Battle Creek Valley, 8 mi. E Hermosa, 1 (NRW). HARDING COUNTY: $10 \mathrm{mi} . \mathrm{S}, 5 \mathrm{mi}$. W Reva, 1. LAWRENCE COUNTY: 2 mi. E Tinton, $5400 \mathrm{ft} ., 1$. PENNINGTON COUNTY: Rapid City, I (NRW); $14 \mathrm{mi}$. W Hill City, $6400 \mathrm{ft}$., 1. County unknown: Moreau River, 1 (USNM).

Additional records.-CLAY COUNTY: Vermillion (Findley, 1956:23). HAND COUNTY: St. Lawrence (E. J. Hugghins, personal communication). STANLEY COUNTY: Ft. Pierre (Miller, 1897:114). WALWORTH COUNTY: "near Swan Creek" (record on file, U. S. Biological Survey-see below).

Like the red bat, the hoary bat is a migrant, occurring in South Dakota only in late spring and summer. The species evidently is statewide in distribution in suitable habitats. All specimens examined are females or young of the year save one adult male (testes 5.5) taken on July 14, 1961, $2 \mathrm{mi}$. E Tinton in the Black Hills. It may be that the Black Hills region is one of the few places in the central Great Plains where males and females accur together, because adult females ordinarily occupy the plains and adjacent lowland regions to the east in summer, whereas males usually are found in montane areas to the west of South Dakota or occasionally at higher latitudes (see Findley and Jones, 1964).

An adult female from $14 \mathrm{mi}$. W Hill City was lactating when taken on June 15, 1965. The three specimens from Sand Creek Park, Bon Homme County, all females that were captured in a mist net on July 26 , 1965, are nearly adult-sized young of the year (weight 21.0-21.7). The record cited above from "near Swan Creek," Walworth County, is of a 
specimen obtained on July 9, 1904, that was identified for S. S. Visher by H. H. T. Jackson. Almost certainly this same bat was the basis of Visher's (1914:92) report of a July-taken individual of this species from the "mouth of the Moreau River," which is on the west side of the Missouri River directly opposite the mouth of Swan Creek.

A hoary bat that bit a woman in St. Lawrence, Hand County, on September 10, 1961, is the only rabid bat thus far (to 1965) reported from South Dakota.

\section{Plecotus townsendii pallescens (Miller, 1897)}

\section{Townsend's Big-eared Bat}

Specimens examined (26).-CUSTER COUNTY: Jewel Cave, $5280 \mathrm{ft}, 3$ ( $1 \mathrm{NRW}, 1 \mathrm{UW}$ ); Hell's Canyon, $13 \mathrm{mi}$. W Custer, 7 (USNM); $2 \mathrm{mi}$. W Wind Cave Nat'l Park, 1 (UW); Wind Cave Nat'I Park, 1 (UW); 18 mi. SW Custer, 1 (USNM). HARDING COUNTY: 1 mi. S, 2 mi. W Ludlow, 1; Ludlow Cave, 1 (SDSU); 10 mi. S, 5 mi. W Reva, 2. LAWRENCE COUNTY: "near Chicken Ranch and Roubaix Lake," 1 (NRW). PENNINGTON COUNTY: Rochford, $5300 \mathrm{ft.} 1$ (UMMZ); 2-3 mi. W Rapid City, 1 (NRW); Spring Creek Canyon, 1 (NRW) ; 4 mi. SW Rockerville, $5000 \mathrm{ft}$, 1 (UMMZ); 3 mi. SE Hill City, 3 (UMMZ); Bear Trap Cave, 4 mi. S, 16 mi. W Hill City, $6000 \mathrm{ft}$., 1.

Additional records.-CUSTER COUNTY: $4 \mathrm{mi}$. W Fairburn (Tyers, Bat Banding News, 4:17, 1963). JACKSON COUNTY: no specific locality (Over and Churchill, 1945:9). PENNINGTON COUNTY: mouth of Spring Creek, Cheyenne River (Handley, 1959:195). SHANNON COUNTY: no specific locality in Washington County [merged with Shannon County in 1943] (Over and Churchill, 1945:9). County unknown: Crowfeet (Handley, 1959:195).

This species is found only in the western part of the state. It is commonest in the Black Hills, but occurs also in the pine-clad buttes and hills of Harding County in the northwest, and eastward some distance in the rough canyons along the White and Cheyenne rivers. The easternmost record in the state is from an unspecified locality in Jackson County where Over and Churchill (1945:9) reported that "specimens were taken in an old outbuilding ... in September, 1913." A specimen from this place no doubt is the one on record in the files of the U. S. Biological Survey as collected by Over on September 16, 1913, from the "White River, Stanley Co.," which was listed by Handley (1959:197). The White River does not flow through any part of Stanley County but does form the southern boundary of Jackson County. Therefore, Handley's map (fig. 22, p. 186) of the distribution of P. townsendii shows pallescens occurring farther to the east in South Dakota than likely in the case.

A population of aproximately 2000 individuals of this species winters in company with several other species in Jewel Cave, Custer County, but Plecotus vacates the cave entirely in late spring and for most of the summer. Not one living long-eared bat was found in the cave when we 
visited there on June 12,1965. Many bats from Jewel Cave have been banded by John Tyers and associates of the U. S. National Park Service, who are studying population trends and dispersal of bats that winter in the cave.

\section{Species Possibly Occurring in South Dakota}

At least three species of bats as yet unreported from South Dakota may occur in the state. One of these, the eastern pipistrelle, Pipistrellus subflavus subflavus (F. Cuvier, 1832), is known from eastern Nebraska (Jones, 1964:89-90), northwestern Iowa (D. A. Schlitter, personal communication), and central Minnesota (Gunderson and Beer, 1953:55). It seems likely this bat will be found in southeastern South Dakota.

The evening bat, Nycticeius humeralis humeralis (Rafinesque, 1818) has been reported from the Platte River Valley in east-central Nebraska (Jones, op. cit.:98) and is to be looked for along the Missouri River and its tributaries in the extreme southeastern part of the state. Additionally, the rare spotted bat, Euderma maculatum (J. A. Allen, 1891), has been recorded from as near the state as south-central Montana and northern Wyoming and possibly will be found in the Black Hills.

\section{Literature Cited}

ALLEN, J. A.

1895. List of mammals collected in the Black Hills region of South Dakota and in western Kansas by Mr. Walter W. Granger, with field notes by the collector. Bull. Amer. Mus. Nat. Hist., 7:259-274, August 21.

BOLE, B. P., Jr.

1953. Myotis thysanodes in South Dakota. J. Mamm., 16:147-148, May 15. FINDLEY, J. S.

1956. Mammals of Clay County, South Dakota. Univ. South Dakota Publ. Biol., 1:1-45, 3 figs., May 15.

FINDLEY, J. S., and C. Jones

1964. Seasonal distribution of the hoary bat. J. Mamm., 45:461-470, 17 figs., September 15.

Glass, B. P., and R. J. BAKer

1965. Vespertilio subulatus Say, 1823: proposed suppression under the plenary powers (Mammalia, Chiroptera). Bull. Zool. Nomenclature, 22:204205, August.

GUNDERSON, H. L., and J. R. BEER

1953. The mammals of Minnesota. Occas. Papers Minnesota Mus. Nat. Hist., $6: x i i+1-190$, illustrated.

HANDLEY, C. O., Jr.

1959. A revision of American bats of the genera Euderma and Plecotus. Proc. U. S. Nat. Mus., 110:95-246, 27 figs., September 3.

JoNes, J. K., Jr.

1964. Distribution and taxonomy of mammals of Nebraska. Univ. Kansas Publ., Mus. Nat. Hist., 16:1-356, 4 pls., 82 figs., October 1.

JONES, J. K., Jr., and H. H. Genoways

1967. A new subspecies of the fringe-tailed bat, Myotis thysanodes, from the Black Hills of South Dakota and Wyoming. J. Mamm., 48:231-235, 2 figs., May 20. 
Jones, J. K., Jr., and R. L. PACKARD

1958. Myotis keenii septentrionalis in South Dakota. J. Mamm., 39:150, February 20.

Kohls, G. M., D. E. Sonenshine, and C. M. Clifford

1965. The systematics of the subfamily Ornithodorinae (Acarina: Argasidae). II. Identification of the larvae of the Western Hemisphere and descriptions of three new species. Ann. Ent. Soc. Amer., 58:331-364, 62 figs., May.

LoNG, C. A.

1965. The mammals of Wyoming. Univ, Kansas Publ., Mus. Nat. Hist., $14: 493-758,82$ figs., July 6.

MilleR, G. S., Jr.

1897. Revision of the North American bats of the family Vespertilionidae. N. Amer. Fauna, 13:1-140, 3 pls., 40 figs., October 16.

Miller, G. S., Jt., and G. M. AlleN

1928. The American bats of the genera Myotis and Pizonyx. Bull U. S. Nat. Mus., 144:viii + 1-218, 1 pl., 1 fig., 13 maps, May 25.

Moulthrop, P. N.

1936. Myotis volans interior in South Dakota. J. Mamm., 17:413-414, November 14.

Over, W. H., and E. P. Churchill

1945. Mammals of South Dakota. Univ. South Dakota Mus., (3) $+56+$ 3 pp., 1 fig., mimeographed.

REAGAN, A. B.

1908. Animals, reptiles and amphibians of the Rosebud Indian Reservation, South Dakota. Trans. Kansas Acad. Sci., 21:163-164.

Stebler, A. M.

1939. An ecological study of the mammals of the Badlands and the Black Hills of South Dakota and Wyoming. Ecology, 20:382-393, 3 figs., July.

VISHER, S. S.

1914. A preliminary report on the biology of Harding County, northwestern South Dakota. Bull. South Dakota Geol. Surv., 6:1-103, 6 pls.

-Museum of Natural History, The University of Kansas, Lawrence. 